\title{
Stunting dan Faktor yang Berhubungan Studi Kasus Kontrol di Wilayah Kerja Puskesmas Baitussalam Kabupaten Aceh Besar
}

\section{Stunting and Associated Factors Case Control Study the Baitussalam Community Health Center, Aceh Besar District}

\author{
Chairanisa Anwar*1, Mira Abdullah², Vellia Sasmita ${ }^{3}$ \\ ${ }^{1}$ Universitas Ubudiyah Indonesia, Jalan Alue Naga Desa Tibang, Banda Aceh, Indonesia \\ ${ }^{2}$ Universitas Ubudiyah Indonesi, Jalan Alue Naga Desa Tibang, Banda Aceh, Indonesia \\ ${ }^{3}$ Mahasiswa Program Studi D-III Kebidanan Universitas Ubudiyah Indonesi, Jalan Alue Naga Desa Tibang, Banda Aceh, \\ Indonesia \\ *Corresponding Author : chaira.anwar@uui.ac.id
}

\begin{abstract}
Abstrak
Kejadian balita pendek atau biasa disebut dengan stunting merupakan salah satu masalah gizi yang dialami oleh balita di dunia. Pada tahun 2017 22,2\% atau sekitar 150,8 juta balita di dunia mengalami stunting. Namun angka ini sudah mengalami penurunan jika dibandingkan dengan angka stunting pada tahun 2000 yaitu 32,6\%. Kejadian balita stunting (pendek) merupakan masalah gizi utama yang dihadapi Indonesia. Berdasarkan data Pemantauan Status Gizi (PSG) selama tiga tahun terakhir, pendek memiliki prevalensi tertinggi dibandingkan dengan masalah gizi lainnya seperti gizi kurang, kurus, dan gemuk. Prevalensi balita pendek mengalami peningkatan dari tahun 2016 yaitu 27,5\% menjadi 29,6\% pada tahun 2017. Prevalensi balita pendek di Indonesia cenderung statis. Hasil Riset Kesehatan Dasar (Riskesdas) tahun 2007 menunjukkan prevalensi balita pendek di Indonesia sebesar 36,8\%. Pada tahun 2010, terjadi sedikit penurunan menjadi $35,6 \%$. Namun prevalensi balita pendek kembali meningkat pada tahun 2013 yaitu menjadi 37,2\%. Prevalensi balita pendek selanjutnya akan diperoleh dari hasil Riskesdas tahun 2018 yang juga menjadi ukuran keberhasilan program yang sudah diupayakan oleh pemerintah (Pusdatin, 2018).

Aceh menduduki peringkat tiga nasional untuk angka stunting balita, di bawah Nusa Tenggara Timur (NTT) dan Sulawesi Barat (sulbar). Saat ini, urainya, pemerintah gencar mengampanyekan gerakan pencegahan dan penanganan stunting. Sebab, prevalensi stunting bayi berusia di bawah lima tahun (balita) Indonesia pada 2018 sebesar 30,8\%. Angka ini berada di atas ambang yang ditetapkan WHO sebesar $20 \%$. Penyebab stunting ada banyak hal atau multifaktor. Karena itu, penyelesaiannya pun harus dilakukan secara multisektor. Secara khusus, apresiasi harus diberikan untuk Pemerintah Aceh karena dalam lima tahun terakhir Pemerintah Aceh mampu menurunkan prevalensi stunting dari 41,5\% di 2013 menjadi 37,3\% pada 2018, yang artinya Pemerintah Aceh menyelamatkan 18 ribu balita dari stunting. Meski demikian, Aceh tetap harus bekerja keras karena saat ini berada di peringkat ketiga prevalensi stunting tertinggi di Indonesia (Aripin et al., 2018).

Tujuan penelitian ini adalah untuk mengetahui faktor-faktor yang berhubungan dengan kejadian stunting di Puskesmas Baitussalam Kabupaten Aceh Besar Tahun 2020. Jenis penelitian ini adalah analitik. Populasi dalam penelitian ini adalah seluruh ibu yang memiliki balita usia 0-60 bulan yang bertempat tinggal di wilayah kerja Puskemas Baitussalam Kabupaten Aceh Besar Juli 2017 yang berjumlah 1923 balita. Sampel penelitian dibagi menjadi dua kelompok yaitu kelompok kasus dengan 60 balita stunting dan kelompok kontrol sebanyak 60 balita non stunting, dengan jumlah 120 responden. Analisis yang digunakan adalah analisis bivariat.
\end{abstract}


Journal of Healthcare Technology and Medicine Vol. 6 No. 2 Oktober 2020

Universitas Ubudiyah Indonesia

e-ISSN : 2615-109X

Kata Kunci: Stunting, Balita, Faktor yang berhubungan

\section{Abstract}

The incidence of short children or commonly referred to as stunting is one of the nutritional problems experienced by toddlers in the world today. In $201722.2 \%$ or around 150.8 million children under five in the world were stunted. However, this figure has decreased when compared to the stunting rate in 2000, which was $32.6 \%$. The incidence of stunting (short) children is a major nutritional problem facing Indonesia. Based on Nutritional Status Monitoring (PSG) data for the last three years, stunting has the highest prevalence compared to other nutritional problems such as malnutrition, thinness, and obesity. Aceh is ranked third nationally for child stunting, behind East Nusa Tenggara (NTT) and West Sulawesi (Sulbar). Currently, he explained, the government is aggressively campaigning for the prevention and handling of stunting. This is because the prevalence of stunting for infants under five years of age (toddlers) in Indonesia in 2018 was $30.8 \%$. This figure is above the WHO threshold of $20 \%$.

The purpose of this study is for factors related to the incidence of stunting in the Baitussalam Community Health Center, Aceh Besar District in 2020. This type of research is analytical. The population in this study were all mothers who have toddlers aged 0-60 months who live in the work area of the Baitussalam Puskemas, Aceh Besar District, July 2017, totaling 1923 toddlers. The research sample was divided into two groups, namely the case group with 60 stunting infants and the control group with 60 non-stunting toddlers, with a total of 120 respondents. The analysis used was bivariate analysis.

Key words: stunting, toddlers , related factors

\section{PENDAHULUAN}

Kejadian balita pendek atau biasa disebut dengan stunting
merupakan salah satu masalah gizi yang dialami oleh balita di dunia termasuk Indonesia. Prevalensi balita pendek mengalami peningkatan dari tahun 2016 yaitu 27,5\% menjadi 29,6\% pada tahun 2017. Prevalensi balita pendek di Indonesia cenderung statis. Hasil Riset Kesehatan Dasar (Riskesdas) tahun 2007 menunjukkan prevalensi balita pendek di Indonesia sebesar 36,8\%. Pada tahun 2010, terjadi sedikit penurunan menjadi 35,6\%. Namun prevalensi balita pendek kembali meningkat pada tahun 2013 yaitu menjadi 37,2\%. Prevalensi balita pendek selanjutnya akan diperoleh dari hasil Riskesdas tahun 2018 yang juga menjadi ukuran keberhasilan program yang sudah diupayakan oleh pemerintah (Pusdatin, 2018).

Nutrisi yang diperoleh sejak bayi lahir tentunya sangat berpengaruh terhadap pertumbuhannya termasuk risiko terjadinya stunting. Tidak terlaksananya inisiasi menyusu dini (IMD), gagalnya pemberian air susu ibu (ASI) eksklusif, dan proses penyapihan dini dapat menjadi salah satu faktor terjadinya stunting. Sedangkan dari sisi pemberian makanan pendamping ASI (MP ASI) hal yang perlu diperhatikan adalah kuantitas, kualitas, dan keamanan pangan yang diberikan. Merujuk pada pola pikir UNICEF/Lancet, masalah stunting terutama disebabkan karena ada pengaruh dari pola asuh, cakupan dan kualitas pelayanan kesehatan, lingkungan, dan ketahanan pangan, maka berikut ini mencoba untuk membahas dari 
Journal of Healthcare Technology and Medicine Vol. 6 No. 2 Oktober 2020

Universitas Ubudiyah Indonesia

e-ISSN : 2615-109X

sisi pola asuh dan ketahanan pangan tingkat keluarga. Dari kedua kondisi ini dikaitkan dengan strategi implementasi program yang harus dilaksanakan. Pola asuh (caring), termasuk di dalamnya adalah Inisiasi Menyusu Dini (IMD), menyusui eksklusif sampai dengan 6 bulan, dan pemberian ASI dilanjutkan dengan makanan pendamping ASI (MPASI) sampai dengan 2 tahun merupakan proses untuk membantu tumbuh kembang bayi dan anak (Kementerian Kesehatan RI, 2018).

Aceh menduduki peringkat tiga nasional untuk angka stunting balita, di bawah Nusa Tenggara Timur (NTT) dan Sulawesi Barat (sulbar). Saat ini, urainya, pemerintah gencar mengampanyekan gerakan pencegahan dan penanganan stunting. Sebab, prevalensi stunting bayi berusia di bawah lima tahun (balita) Indonesia pada 2018 sebesar 30,8\%. Angka ini berada di atas ambang yang ditetapkan WHO sebesar 20\%. Selain itu, di Asia Tenggara, Indonesia juga menduduki peringkat kedua setelah Laos. Penyebab stunting ada banyak hal atau multifaktor. Karena itu, penyelesaiannya pun harus dilakukan secara multisektor. Di sinilah komitmen pemimpin negara harus kuat, yang selanjutnya diteruskan di level pemimpin daerah hingga kabupaten dan kota. Secara khusus, apresiasi harus diberikan untuk Pemerintah Aceh karena dalam lima tahun terakhir Pemerintah Aceh mampu menurunkan prevalensi stunting dari 41,5\% di 2013 menjadi 37,3\% pada 2018, yang artinya Pemerintah Aceh menyelamatkan 18 ribu balita dari stunting. Meski demikian, Aceh tetap harus bekerja keras karena saat ini berada di peringkat ketiga prevalensi stunting tertinggi di Indonesia (Aripin et al., 2018).

Prevalensi stunting di Kecamatan Baitussalam adalah 26\%. Dilihat dari angka prevalensi stunting di tingkat provinsi Aceh maupun Kabupaten Aceh Besar dan kecamatan Baitussalam masih diatas ambang batas (cut of point) yang telah disepakati secara universal, dimana apabila masalah stunting diatas $20 \%$ maka masih merupakan masalah kesehatan masyarakat (Kementerian PPN/ Bappenas, 2018).

Data Stunting di Kecamatan Baitussalam bulan Juni 2020 berjumlah 134 balita, kenaikan jumlah kasus stunting terjadi pada bulan Juli 2020 yaitu 215 kasus, dan 158 kasus stunting pada bulan Agustus 2020 (Data Puskesmas Baitussalam, 2020).

\section{METODE PENELITIAN}

Jenis penelitian ini adalah penelitian analitik observasional dengan rancangan penelitian kasus kontrol (case control study), merupakan penelitian epidemiologi analitik observasional yang berusaha melihat ke belakang (backward looking), artinya pengumpulan data dimulai dari efek atau akibat yang telah terjadi (kasus), kemudian dari efek tersebut ditelusuri ke belakang tentang penyebabnya atau variabel yang mempengaruhi akibat tersebut (kontrol) (Sinaga et al., 2015).

Populasi dalam penelitian ini adalah seluruh ibu yang memiliki Balita usia 0-60 bulan yang bertempat tinggal di wilayah kerja Puskemas Baitussalam Kabupaten Aceh Besar periode Juli 2017 sebanyak 1923 balita. Berdasarkan hasil perhitungan besar sampel, maka diketahui bahwa jumlah sampel terbesar adalah sebanyak 60 responden. Sehingga jumlah sampel kasus dapat ditentukan sebesar 60 responden. Jumlah sampel kontrol di ambil berdasarkan perbandingan 1 kasus dan 1 kontrol (1:1), sehingga jumlah sampel kontrol sama dengan jumlah sampel kasus yaitu sebanyak 60 responden. Total keseluruhan sampel adalah 
Journal of Healthcare Technology and Medicine Vol. 6 No. 2 Oktober 2020

Universitas Ubudiyah Indonesia

e-ISSN : 2615-109X

120 responden. Pengmpulan data dilakukan selama 2 bulan yaitu Juli dan Agustus 2020 di Wilayah Kerja Puskesmas Baitussalam Kabupaten Aceh Besar. Pengolahan data menggunakan computer melalui proses editing, coding, transferring dan tabulating. Analisis data dengan dua data yaitu analisis univariat, bivariat dan multivariat.

\section{HASIL}

1. Analisa Univariat

\begin{tabular}{clllc}
\hline No & Variabel & Kategori & $\mathbf{N}$ & $\%$ \\
\hline 1. & Stunting & Stunting & 60 & 50,0 \\
& & Tidak Stunting & 60 & 50,0 \\
\hline 2. & Pengetahuan Ibu & Rendah & 48 & 40,0 \\
& & Tinggi & 72 & 60,0 \\
\hline 3. & \multirow{2}{*}{ Kelengkapan Imunisasi } & Tidak lengkap & 64 & 53,3 \\
& & Lengkap & 56 & 46,7 \\
\hline 4. & Pemberian ASI eksklusif & Tidak eksklusif & 53 & 44,2 \\
& & Eksklusif & 67 & 55,8 \\
\hline 5. & Penyakit Infeksi & Ada & 62 & 57,1 \\
& & Tidak & 58 & 48,3 \\
\hline 6. & Pendapatan Keluarga & Rendah & 63 & 52,5 \\
& & Tinggi & 57 & 47,5 \\
\hline
\end{tabular}

\section{Analisa Bivariat}

\begin{tabular}{|c|c|c|c|c|c|c|c|}
\hline \multirow{2}{*}{$\begin{array}{c}\text { Variabel } \\
\text { Independen }\end{array}$} & \multicolumn{4}{|c|}{ Stunting pada Balita } & \multicolumn{2}{|c|}{ Total } & \multirow[b]{2}{*}{ P- Value } \\
\hline & Stunting & $\%$ & $\begin{array}{c}\text { Tidak } \\
\text { Stunting }\end{array}$ & $\%$ & $\mathbf{f}$ & $\%$ & \\
\hline \multicolumn{8}{|l|}{ Pengetahuan Ibu } \\
\hline 1. Rendah & 32 & 66.7 & 16 & 33.3 & 60 & 100 & 0.005 \\
\hline 2. Tinggi & 28 & 38.9 & 44 & 61.1 & 60 & 100 & \\
\hline \multicolumn{8}{|l|}{ Imunisasi } \\
\hline 1. Tidak lengkap & 28 & 43.8 & 36 & 56.3 & 64 & 100 & 0.583 \\
\hline 2. Lengkap & 32 & 57.1 & 24 & 42.9 & 56 & 100 & \\
\hline \multicolumn{8}{|l|}{ ASI Eksklusif } \\
\hline 1. Tidak & 22 & 41.5 & 31 & 58.5 & 53 & 100 & 0.542 \\
\hline 2. $\mathrm{Ya}$ & 38 & 56.7 & 29 & 43.3 & 67 & 100 & \\
\hline \multicolumn{8}{|l|}{ Penyakit Infeksi } \\
\hline 1. Ada & 38 & 61.3 & 24 & 38.7 & 62 & 100 & 2.591 \\
\hline 2. Tidak & 22 & 37.9 & 36 & 62.1 & 58 & 100 & \\
\hline \multicolumn{8}{|l|}{ Pendapatan } \\
\hline \multicolumn{8}{|l|}{ Keluarga } \\
\hline 1. Rendah & 38 & 60.3 & 25 & 39.7 & 63 & 100 & 0.028 \\
\hline 2. Tinggi & 22 & 38.6 & 35 & 61.4 & 57 & 100 & \\
\hline
\end{tabular}




\section{Analisa Univariat}

\begin{tabular}{|c|c|c|c|c|c|}
\hline No & Variabel & $\begin{array}{l}\text { Nilai } \\
\text { P }\end{array}$ & OR & $95 \% \mathrm{CI}$ & Pemodelan \\
\hline 1. & Pengetahuan Ibu & 0,005 & 3,143 & $1,463-6,751$ & $\begin{array}{l}\text { Masuk } \\
\text { pemodelan }\end{array}$ \\
\hline 2. & Kelengkapan Imunisasi & 0,200 & 0,583 & $0,283-1,203$ & $\begin{array}{l}\text { Tidak masuk } \\
\text { pemodelan }\end{array}$ \\
\hline 3. & Pemberian ASI & 0,141 & 0,542 & $0,261-1,123$ & $\begin{array}{l}\text { Tidak Masuk } \\
\text { pemodelan }\end{array}$ \\
\hline 4. & Penyakit Infeksi & 0,011 & 2,591 & $1,240-5,412$ & $\begin{array}{l}\text { Masuk } \\
\text { pemodelan }\end{array}$ \\
\hline 5. & Pendapatan Keluarga & 0,028 & 2,418 & $1,160-5,039$ & $\begin{array}{l}\text { Tidak Masuk } \\
\text { pemodelan }\end{array}$ \\
\hline
\end{tabular}

\section{PEMBAHASAN}

\section{Pengaruh Pengetahuan Ibu terhadap Stunting}

Keadaan status gizi akan ditentukan oleh faktor internal dan eksternal. Faktor eksternal yang mempengaruhi antara lain ketersediaan bahan pangan pada suatu daerah, lingkungan tempat tinggal, dan pelayanan kesehatan yang tersedia di daerah tempat tinggal. Sedangkan faktor internal, antara lain cukup tidaknya pangan seseorang dan kemampuan tubuh menggunakan pangan tersebut. Cukup tidaknya pangan dapat dilihat dari pola makan yang dilakukan sehari-hari. Pola makan tersebut tergantung pada pengetahuan gizi yang dimiliki oleh penyelenggara makanan. Seperti yang dikemukakan Nency (2015), bahwa stunting disebabkan oleh kekurangan asupan makanan yang kurang, yang disebabkan oleh tidak tersedianya makanan yang adekuat, anak tidak cukup mendapat makanan bergizi seimbang, dan pola makan yang salah.

Dalam hal ini orang tua sangat berperan untuk memperhatikan masalah gizi sang anak. Seperti telah diketahui bahwa seorang ibu merupakan sosok yang menjadi tumpuan dalam mengelola makan keluarga. Jadi, secara tidak langsung kesejahteraan pangan keluarga akan sangat tergantung pada ibu. Semakin baik pengelolaan makan yang dilakukan oleh ibu, maka akan semakin pula pola makan keluarga. Sehingga dalam pemberian makan tersebut penting pula untuk diperhatikan asupan gizinya karena hal tersebut akan berpengaruh pada status gizi keluarga, khususnya anak. Semua itu tak lepas dari kemampuan ibu dalam memilih, mengolah, serta mengatur makan yang dibutuhkan oleh anggota keluarga. Hal yang mendasari pengelolaan makan keluarga adalah pengetahuan gizi yang dimiliki oleh ibu. Secara tidak langsung kebiasaan makan yang dilakukan ibu akan mempengaruhi kebiasaan makan anak. 
Pada masa balita anak merupakan golongan konsumen pasif, yaitu belum dapat mengambil dan memilih makanan sendiri. Sesuai dengan yang dikemukakan Asparno Mardjuki dan Satoto, bahwa gizi memang penting dalam pertumbuhan dan perkembangan otak yang $98 \%$ terjadi pada anak usia balita. Maka bila terjadi kesalahan pemberian gizi pada anak balita akan mengganggu perkembangan otak anak tersebut. Untuk itu, pemberian makan pada anak hendaknya lebih memperhatikan kandungan gizi agar kebutuhan gizi yang diperlukan oleh tubuh anak dapat terpenuhi sehingga perkembangan dan pertumbuhan anak tidak mengalami hambatan atau gangguan (Subrahmanian \& Swamy, 2018).

Pengetahuan gizi meliputi segala bentuk informasi mengenai zat-zat makanan termasuk sumber dan fungsinya yang diperlukan bagi tubuh serta penerapannya dalam kehidupan sehari-hari. Sehingga pengetahuan ibu tentang gizi balita merupakan segala bentuk informasi yang dimiliki oleh ibu mengenai zat makanan yang dibutuhkan bagi tubuh balita dan kemampuan ibu untuk menerapkannya dalam kehidupan sehari-hari (Yakub et al., 2008).

Berbagai penelitian telah membuktikan bahwa masalah gizi adalah masalah intergenerasi, yaitu ibu hamil kurang gizi akan melahirkan bayi kurang gizi. Pada hakekatnya masalah gizi dapat diselesaikan dalam waktu relatif singkat. Intervensi paket kegiatan untuk mengatasi masalah tersebut yang dilaksanakan melalui pelayanan berkelanjutan (continuum care) pada periode kesempatan emas kehidupan (window of opportunity), yaitu sejak janin dalam kandungan, dan bayi baru lahir sampai anak berusia 2 tahun (DT, 2011).

Letak geografis Kecamatan Baitussalam yang luas mencakup 13 Desa menyebabkan informasi-informasi penting tentang gizi balita menjadi kendala dimana masyarakat di desa-desa terpencil yang jaraknya jauh dari Puskesmas sangat sulit mendapatkan pantauan dari kader-kader gizi Puskesmas tentang keadaan gizi balita masyarakat tersebut. Selain itu, faktor yang mempengaruhi pengetahuan ibu tentang gizi yang rendah adalah tingkat pendidikan ibu yang mayoritas adalah tamatan SD sebanyak 21 ibu (\%). Tingkat pendidikan akan mempengaruhi pengetahuan seseorang sehingga membuat seseorang berpandangan luas, berpikir dan bertindak rasional karena semakin tinggi tingkat pendidikan responden maka tingkat pengetahuannya akan semakin baik, sehingga responden mudah menerima informasi dan semakin banyak pula pengetahuan yang dimilikinya. Semakin baik pengetahuan gizi seseorang, maka orang tersebut akan semakin memperhatikan kuantitas dan kualitas pangan yang akan dikonsumsinya. Orang yang tidak mempunyai cukup pengetahuan tentang gizi, akan memilih makanan yang baik menurut panca inderanya dan tidak mengadakan pilihan makanan berdasarkan nilai gizi makanannya. Sebaliknya orang yang semakin baik pengetahuan tentang gizinya akan lebih banyak mempergunakan pertimbangan rasional dan pengetahuannya sebagai dasar sebelum mengkonsumsi makanan. Penyediaan bahan dan menu makan yang tepat untuk balita dalam upaya peningkatan status gizi akan dapat terwujud bila ibu mempunyai tingkat pengetahuan gizi yang baik. Ketidaktahuan mengenai informasi tentang gizi dapat menyebabkan kurangnya mutu atau kualitas gizi makanan keluarga khususnya makanan yang dikonsumsi balita. Salah satu penyebab gangguan gizi adalah kurangnya pengetahuan 
gizi dan kemampuan seseorang menerapkan informasi tentang gizi dalam kehidupan sehari-hari. Tingkat pengetahuan gizi ibu mempengaruhi sikap dan perilaku dalam memilih bahan makanan, yang lebih lanjut akan memengaruhi keadaan gizi keluarganya.

\section{Pengaruh Kelengkapan Imunisasi terhadap Stunting}

Upaya yang dilakukan pemerintah untuk terus menekan angka kematian bayi dan balita serta menghindari terjadinya sakit adalah dengan mengeluarkan Program Imunisasi Nasional. Program Imunisasi dasar lengkap yang telah dilakukan pada kenyataannya tidak seluruhnya berhasil dan masih banyak bayi atau balita yang status kelengkapan imunisasinya belum lengkap. Imunisasi membantu anak terhindar dari penyakit yang ganas, dengan reaksi antigen-antibodi itu tubuh anak memberikan reaksi perlawanan terhadap benda-benda asing dari luar tubuh seperti kuman, virus, racun dan bahkan bahan kimia yang merusak tubuh sehingga anak tidak mudah terkena infeksi yang akan berpengaruh terhadap status gizinya. Kurangnya asupan zat gizi akibat nafsu makan yang turun dan adanya penyakit, secara langsung mempengaruhi status gizi anak balita (Hardinsyah \& Supariasa, 2016).

Peneliti berasumsi bahwa imunisasi merupakan pemberian kekebalan buatan terhadap tubuh anak dengan memasukkan kuman lemah yang berfungsi untuk memberi kekebalan terhadap tubuh dari jenis penyakit tertentu, sehingga tidak semua balita yang lengkap imunisasi dasar mampu membentengi tubuhnya dari paparan penyakit, mengingat ada faktor lain yang memiliki peran dominan terhadap kekebalan aktif tubuh yaitu asupan makanan yang baik selama usia anak di atas 6 bulan. Kekebalan alamiah pun sudah diwariskan ibu dari pemberian ASI eksklusif selama 6 bulan. Dari hasil penelitian didapatkan bahwa ibu di wilayah kerja Puskesmas tempat penelitian sudah sangat sadar akan manfaat pemberian ASI eksklusif, terbukti dari banyaknya responden yang memberikan ASI saja selama 6 bulan. Para ibu di tempat penelitian masih terikat pemahaman keliru mengenai halalnya pemberian imunisasi, sebagian mereka masih enggan untuk mengijinkan anaknya diimunisasi. Feneomena ini yang peneliti dapatkan ketika mewawancarai responden. Mereka mengira bahwa ada zat-zat yang terkandung dalam vaksin yang tidak halal. Sehingga paham ini yang nantinya akan merugikan anak. Sehingga akan sulit bagi praktisi pelayan kesehatan untuk memvaksin anak-anak mereka. Untuk itu perlu disiasati dari penggalakkan pemberian ASI secara eksklusif agar tidak memperparah keadaan ke depannya.

Faktor lainnya yang lebih dominan adalah pemberian ASI eksklusif, dimana dengan lengkapnya imunisasi saja tidak menjadi jaminan untuk seorang balita terbebas dari penyakit, karena imunisasi dasar hanya memproteksi terhadap penyakit tertentu. Berdasarkan penelitian dapat disimpulkan bahwa hal yang paling mungkin untuk mengeliminasi masalah gizi buruk adalah dengan memberikan ASI saja sampai usia 6 bulan, dan memberikan makanan bergizi dan beragam setalah usia balita diatas 6 bulan.

\section{Pemberian ASI Eksklusif terhadap Stunting}

Air Susu Ibu menjadi makanan ideal untuk tumbuh kembang bayi, bayi yang tidak memperoleh ASI, hanya diberi susu formula pada bulan pertama kehidupannya, memiliki risiko tinggi untuk menderita gizi buruk, diare, alergi dan penyakit infeksi lainnya. Hal ini 
tentu akan berpengaruh terhadap proses pertumbuhan dan perkembangan bayi (Nursalam, 2012).

Pemberian ASI eksklusif pada usia 6 bulan pertama merupakan satu-satunya waktu ketika para bayi dan ibunya miskin atau kaya berada pada kondisi yang sama sebagaimana disebutkan oleh James Grant (mantan direktur Unicef) "Pemberian ASI merupakan jaring pengaman alami terhadap efek terburuk oleh kemiskinan. Jika seorang anak dapat melalui bulan pertama kehidupannya yaitu periode usia kanak-kanak yang paling berbahaya) maka 4 bulan berikutnya atau seterusnya, pemberian ASI akan melewati jalan yang panjang untuk menghilangkan perbedaan kesehatan antara bayi yang lahir dalam kemiskinan dan bayi yang lahir dalam kelimpahan. Pemberian ASI hampir mirip tindakan mengentaskan bayi dari kemiskinan selama beberapa bulan pertama untuk memberikan titik start yang lebih adil dalam kehidupan dan mengimbangi ketidakadilan dunia yang menjadi tempat kelahiran bayi itu".

Air Susu Ibu (ASI) menjadi makanan yang paling sesuai untuk bayi karena mengandung zat-zat gizi yang diperlukan oleh bayi untuk tumbuh dan berkembang. Pentingnya memberikan ASI secara eksklusif pada bayi baru lahir sampai usia 6 bulan dan terus memberikan ASI sampai anak berusia 24 bulan telah memiliki bukti yang kuat. Beberapa penelitian telah membuktikan bahwa bayi yang diberi ASI eksklusif menunjukkan perkembangan sosial dan kognitif yang lebih baik dari bayi yang diberi susu formula (Kramer, 2010). Efek jangka panjang dari pemberian ASI pada anak dan kesehatan mental remaja telah diteliti secara cohort pada 2900 ibu hamil yang diteliti selama 14 tahun di Australia. Penelitian yang dipublikasikan pada tahun 2009 ini menyimpulkan bahwa pemberian ASI yang singkat (kurang dari 6 bulan) menjadi prediktor dari berbagai masalah kesehatan mental yang akan muncul pada masa anak dan remaja, seperti autis, kenakalan remaja, agitasi, dan lain sebagainya. Bahkan IQ anak yang diberi ASI ditemukan 13 poin lebih baik daripada bayi yang tidak diberikan ASI (Oddy, 2017).

Balita yang tidak mendapatkan ASI eksklusif tidak memperoleh kandungan nutrisi dalam ASI secara penuh sehingga kekebalan tubuhnya akan lebih rendah dan berdampak pada lebih seringnya terkena penyakit. Dimana hal ini akan mempengaruhi status gizi balita. Sedangkan balita yang mendapatkan kandungan ASI selama 6 bulan akan memperoleh nutrisi dan kekebalan tubuh yang baik terhadap penyakit. Sehingga tubuh balita dapat tumbuh dan berkembang dengan baik. Para ibu harus mengetahui bahwa ASI adalah hak asasi bayi dan perorangan sehingga institusi yang tidak mendukung pemberian ASI akan dikenakan sanksi hukuman dan denda. Cakupan pemberian ASI eksklusif dipengaruhi beberapa hal, terutama masih sangat terbatasnya tenaga konselor laktasi untuk memberikan informasi yang benar kepada keluarga, serta belum maksimalnya kegiatan edukasi, sosialisasi, advokasi, dan promosi terkait pemberian ASI maupun MP-ASI. Rancangan Peraturan Pemerintah tentang Pemberian ASI Eksklusif ke depan diharapkan menjadi pedoman penegakan hukum di daerah untuk mengungkit kenaikan cakupan pemberian ASI eksklusif pada bayi, minimal tercapai 80 persen pada tahun 2015.

\section{Penyakit Infeksi terhadap Stunting}


Dalam satu kali diare, rata-rata durasi sakit yang dialami balita adalah berkisar antara 4-7 hari, namun ada juga yang hanya terjadi selama 1 atau 2 hari. Biasanya orang tua atau pengasuh balita membawa balita ke puskesmas dan memberikan balita obat yang telah diberikan oleh puskesmas. Pada kelompok balita stunting lebih banyak balita yang diasuh dengan hygiene yang buruk yaitu dengan persentase sedangkan pada kelompok balita tidak stunting sebagian besar balita diasuh dengan higiene yang baik. Secara umum, lingkungan tempat tinggal balita pada kedua kelompok (stunting dan tidak stunting) adalah sama, yang membedakan adalah praktik higiene dari masing-masing keluarga, masih banyak keluarga terutama pada kelompok anak stunting yang memiliki kesadaran yang rendah akan pentingnya kebersihan diri dan lingkungan tempat tinggal. Peneliti berpendapat bahwa sebagian besar pengasuh balita masih buruk dalam menjaga kebersihan lingkungan tempat tinggal, kesadaran akan keamanan pangan untuk anak dan kebersihan alat makan masih rendah, masih menggunakan air sumur untuk kebutuhan sehari-hari, dan masih sering membeli cemilan di luar untuk anak. Praktik higiene yang buruk menimbulkan risiko yang tinggi munculnya bakteri. Bakteri-bakteri ini lah yang akan masuk ke tubuh anak melalui makanan yang biasa disajikan di rumah dan dapat berdampak kepada kesehatan anak tersebut, salah satunya seperti timbulnya penyakit diare dan dapat menyebabkan anak kehilangan cairan serta sejumlah zat gizi yang esensial bagi tubuh. Seorang anak yang terkena diare akan mengalami malabsorbsi zat gizi dan durasi diare yang berlangsung lama (lebih dari empat hari) akan membuat anak semakin mengalami kehilangan zat gizi, bila tidak segera ditindaklanjuti dan diimbangi dengan asupan yang sesuai makan terjadi gagal tumbuh. Anak yang kurang gizi akan memiliki daya tahan tubuh terhadap penyakit yang rendah sehingga mudah terkena penyakit infeksi dan dampak penyakit infeksi ini dapat mempengaruhi perkembangan kognitif anak dan menghambat pertumbuhan badan. Diare yang terjadi dalam periode yang panjang pada saat balita berusia dua tahun pertama kehidupan dapat berpengaruh terhadap terjadinya retardasi pertumbuhan.

\section{Pendapatan Keluarga terhadap Stunting}

Salah satu karakteristik keluarga adalah tingkat pendapatan keluarga. Keluarga dengan status ekonomi menengah kebawah, memungkinkan konsumsi pangan dan gizi terutama pada balita rendah dan hal ini mempengaruhi stunting pada anak balita (Batti et al., 2018).

Dengan pendapatan tersebut, akan mempengaruhi daya beli keluarga terutama dalam konsumsi pangan untuk memenuhi gizi keluarga, karena pendapatan merupakan salah satu faktor yang secara tidak langsung mempengaruhi status gizi. Rendahnya pendapatan merupakan rintangan yang menyebabkan orang tersebut tidak mampu membeli pangan dalam jumlah yang diperlukan. Anak-anak yang berasal dari keluarga tingkat ekonomi sosial rendah sangat rawan terhadap gizi kurang, karena anak-anak tersebut mengkonsumsi makanan (energi dan protein) lebih rendah dibandingkan anak-anak dari keluarga berada.

Pendapatan masyarakat rata-rata di daerah wilayah kerja Puskesmas Baitussalam sudah di atas UMP Aceh, sebagian besar penduduk setempat bekerja sebagai pedagang, termasuk wanita yang memiliki balita, sehingga waktu untuk memperhatikan balitanya kurang. Mereka juga sering tidak hadir dalam kegiatan posyandu dan kegiatan yang diadakan kader untuk menambah pengetahuan gizi para ibu-ibu yang memiliki balita. Dengan kurangnya pengetahuan gizi ibu, pola makan balita sering terabaikan. 
Totalitas pendapatan keluarga tidak sepenuhnya digunakan untuk memenuhi kebutuhan makan, sehingga secara langsung pendapatan tidak mempunyai korelasi yang nyata dengan stunting. Hal ini disebabkan tidak ada kecenderungan bahwa responden yang mempunyai pendapatan tinggi dialokasikan untuk pemenuhan kebutuhan pangan yang tinggi pula, demikian juga sebaliknya tidak ada kecenderungan bahwa dengan pendapatan yang rendah alokasi untuk kebutuhan pangan yang rendah. Keluarga-keluarga yang sebenarnya mempunyai penghasilan cukup akan tetapi sebagian anaknya mengalami masalah gizi, karena cara mengatur belanja keluarga yang kurang baik, misalnya untuk pangan disediakan belanja terlalu sedikit lebih banyak diperuntukkan bagi pembelian barangbarang lain.

\section{KESIMPULAN}

1. Variabel pengetahuan ibu terhadap stunting diperoleh nilai $\mathrm{P}=0,052$ dengan nilai $\mathrm{OR}=$ 5,950 (95\%CI:1,223-28,951) yang berarti ibu yang memiliki pengetahuan yang rendah tentang gizi memiliki resiko 5,950 kali memiliki balita yang menderita stunting dibandingkan dengan ibu yang memiliki pengetahuan tinggi tentang gizi.

2. Variabel pendapatan keluarga terhadap stunting diperoleh nilai $\mathrm{P}=0,711(\mathrm{P}>0,05)$, yang berarti tidak ada pengaruh yang signifikan antara pendapatan keluarga dengan stunting. Nilai OR $=0,577$ (95\% CI:0,134-2,484) yang menunjukkan bahwa balita dengan pendapatan keluarga yang tinggi memiliki peluang 0,577 kali lebih beresiko menderita stunting.

3. Variabel pemberian ASI eksklusif terhadap stunting diperoleh nilai $\mathrm{P}=0,033$ dengan nilai $\mathrm{OR}=7,600(95 \% \mathrm{CI}: 1,388-41,617)$ yang berarti responden yang tidak mendapatkan ASI eksklusif memiliki resiko 7,600 kali menderita stunting dibandingkan dengan responden yang mendapatkan ASI eksklusif.

4. Variabel kelengkapan imunisasi terhadap stunting diperoleh nilai $\mathrm{P}=0,064$ yang berarti tidak ada pengaruh kelengkapan imunisasi dengan stunting. Nilai OR=0,175 (95\%CI:0,035-0,868), artinya balita dengan imunisasi lengkap berisiko 0,175 kali mengalami stunting.

\section{SARAN}

1. Promosi kesehatan masih perlu dilakukan lagi untuk meningkatkan pengetahuan dan kesadaran masyarakat akan pentingnya gizi dan kesehatan pada balita terutama mengenai ASI eksklusif, pemberian makan pada balita dan perilaku sanitasi dan mencuci tangan.

2. Promosi kesehatan yang dilakukan di wilayah puskesmas Baitussalam Kabupaten Aceh Besar sebaiknya tidak hanya berorientasi pada aspek kognitif tetapi juga harus lebih jauh lagi kepada aspek perilaku melalui metode promosi kesehatan yang sesuai.

3. Upaya promosi kesehatan harus memperhatikan faktor pendidikan, pendapatan, budaya dan tradisi masyarakat, sehingga penyusunan sasaran program disesuaikan dengan latar belakang pendidikan dan tercapainya integrasi antara budaya dan perilaku kesehatan anak. 
Journal of Healthcare Technology and Medicine Vol. 6 No. 2 Oktober 2020

Universitas Ubudiyah Indonesia

e-ISSN : 2615-109X

\section{DAFTAR PUSTAKA}

Aripin, A., Dwiriani, S. M., Meti, C., \& Kolopaking, R. (2018). Asupan Gizi Mikro: Defisiensi Besi Dan Stunting Pada Anak Usia 6-23 Bulan Di Aceh, Indonesia. Widyakarya Nasional Pangan Dan Gizi (WNPG) “ Percepatan Penurunan Stunting Melalui Revitalisasi Ketahanan Pangan Dan Gizi Dalam Rangka Mencapai Tujuan Pembangunan Berkelanjutan.”

Batti, V. M., Kapantow, N. H., \& Malonda, N. S. H. (2018). HUBUNGAN ANTARJurnal KESMASA POLA ASUH DENGAN STATUS GIZI PADA ANAK USIA 24-59 BULAN DI KECAMATAN RATAHAN KABUPATEN MINAHASA TENGGARA. Jurnal KESMAS.

DT, B. (2011). Pedoman Pelayanan Anak Gizi Buruk. Kementerian Kesehatan RI.

Hardinsyah, \& Supariasa, I. D. N. (2016). Ilmu Gizi Teori \& Aplikasi. In Penerbut Buku Kedokteran EGC.

Kementerian Kesehatan RI. (2018). Situasi Balita Pendek (Stunting) di Indonesia. In Kementerian Kesehatan RI.

Kementerian PPN/ Bappenas. (2018). Pedoman Pelaksanaan Intervensi Penurunan Stunting Terintegrasi di Kabupaten/Kota. Rencana Aksi Nasional Dalam Rangka Penurunan Stunting: Rembuk Stunting.

Kramer, M. S. (2010). "Breast is best": The evidence. Early Human Development. https://doi.org/10.1016/j.earlhumdev.2010.08.005

Nursalam. (2012). Konsep Penerapan Metodologi Penelitian Ilmu Keperawatan Pedoman Skripsi, Tesis Dan Instrumen Penelitian Keperawatan. Jilid 1. In Salemba Medika.

Oddy, W. H. (2017). Breastfeeding, Childhood Asthma, and Allergic Disease. Annals of Nutrition and Metabolism. https://doi.org/10.1159/000457920

Pusdatin, 2018. (2018). Buletin Jendela Data dan Informasi Kesehatan. Topik Utama : Situasi Balita Pendek (Stunting) di Indonesia. Journal of Chemical Information and Modeling.

Sinaga, H. T., Siagian, A., Lubis, Z., \& Aritonang, E. (2015). Using Bubble Score Chart as the Main Media in Nutrition Education to Improve Mothers Knowledge and Child Weight Gain in Deli Serdang Distric, Indonesia. Journal of Biology.

Subrahmanian, K., \& Swamy, P. (2018). What is global health? In SpringerBriefs in Public Health. https://doi.org/10.1007/978-3-319-75136-8_1

Yakub, World Health Organization (WHO), Supariasa, B. dan F., Suhardjo, Soraya, Siregar, Rosidah, Pujiarto, Mahdin, Kemenkes, Depkes RI, \& AsDI, I. dan P. (2008). Peranan Gizi Dan Pola Asuh Dalam Meningkatkan Kualitas Tumbuh Kembang Anak. In Penuntun Diet Anak. 